\title{
LEKSIKON DALAM AKTIVITAS PERTANIAN MASYARAKAT YOGYAKARTA
}

\author{
Ridha Mashudi Wibowo \\ e-mail: mzridha@gmail.com \\ Fakultas Ilmu Budaya, Universitas Gadjah Mada Yogyakarta
}

\begin{abstract}
This research aims to document linguistic category regarding the field of agriculture, from the perspective of society in association with plants and their environment, the elaboration of local wisdom in viewing plants and their environment regarding agriculture as part of their livelihood. The ethnobiology lexicon data and other information in relation to plants in Javanese are compiled in articles, books, and dictionaries along with several native speakers of Javanese who reside in the southern part of DIY. Verbal source of data is obtained by controlled elicitation method and analyzed with component analysis method as well as introspection. The result demonstrates the inventorizing of agricultural terms which encompass words, abbreviation, coinage either monomorphemic or polymorphemic. The variety of agricultural term is used in the society in categorizing plants and their environment and highly regarded local wisdom perspective by the people amidst the emergence of renewal in agriculture. This research contributes to the study of language in agricultural activities in Javanese society, especially Yogyakarta in the perspective of ethnics, especially in the formation of language terms which at some level have become a new identity adopted into Javanese. It is hoped that the results of this study can be used by the wider community in using the agricultural lexicon in accordance with the times without forgetting the preservation of the agricultural lexicon that is part of its local wisdom.
\end{abstract}

Record of Article

Received : 4 Maret 2020

Revised : 3 Mei 2020

Accepted : 22 Agustus 2020

Keyword: agriculture, local wisdom, lexicon. 


\section{PENGANTAR}

Seiring dengan perkembangan zaman dan teknologi modern dewasa ini masyarakat pedesaan berada dalam situasi peralihan dari masa pertanian tradisional ke pertanian modern. Tidak semua perubahan dalam masa peralihan itu berdampak baik dan menguntungkan bagi petani, tetapi secara umum banyak pandangan menyatakan bahwa sistem/model pertanian modern dianggap lebih baik daripada sistem/model pertanian tradisional.

Terkait dengan itu, pemakaian peristilahan modern yang bertumpang tindih dengan peristilahan tradisional dalam pertanian menunjukkan bahwa peristilahan modern belum sepenuhnya dapat diterima sementara peristilahan tradisional perlahanlahan terkikis pemakaiannya. Dalam pemahaman etnosains dapat dimanfaatkan peristilahan/teknologi tradisional yang lebih ramah lingkungan dibandingkan dengan teknologi maju yang kadang kurang selaras. Fakta di atas menyarankan bahwa penelitian etnosains terkait dengan klasifikasi tumbuhan, pengelompokan media tanam, siklus pertanian, dan sistem pertanian menjadi penting. Sementara itu, penelitian mengenai pandangan masyarakat tentang tumbuhan dan lingkungannya menjadi mendesak diinventarisasi dan didokumentasikan melalui wawancara dengan masyarakat Yogyakarta yang telah berusia lanjut. Berangkat dari alasan itu tulisan ini menyajikan penginventarisasian kategori-kategori linguistik yg berkaitan dengan dunia pertanian, diungkapkan bagaimana pandangan masyarakat mengenai tumbuhan dan lingkungannya, dan diuraikan bagaimana kearifan lokal memandang tumbuhan dan lingkungan dalam kaitannya dengan pertanian sebagai bagian dari mata pencahariannya. Data leksikon etnobiologi dan informasi lain yang berkaitan dengan dunia tumbuhtumbuhan dalam bahasa Jawa dikumpulkan dari artikel, buku, dan kamus serta sejumlah penutur bahasa Jawa yang tinggal di bagian selatan Daerah Istimewa Yogyakarta. Data dari sumber lisan ini diperoleh dengan metode elisitasi terkontrol dan dianalisis dengan metode analisis komponen dan introspeksi.

Kata ethnoscience (etnosains) berasal dari kata ethnos (bahasa Yunani) yang berarti bangsa, dan scientia (bahasa Latin) artinya pengetahuan. Oleh sebab itu, etnosains merupakan pengetahuan yang dimiliki oleh suatu komunitas budaya. Ilmu ini mempelajari atau mengkaji sistem pengetahuan dan tipe-tipe kognitif budaya tertentu. Penekanan pada pengetahuan asli dan khas dari suatu komunitas budaya. Menurut Moore (1998) etnosains adalah cabang pengkajian budaya yang berusaha menjelaskan bagaimana pribumi memahami alam mereka. Pribumi biasanya memiliki ideologi dan falsafah hidup yang mempengaruhi mereka dalam mempertahankan hidup. Atas dasar ini, dapat dinyatakan bahwa etnosains merupakan bentuk etnografi baru (the new ethnography). Melalui etnosains sebenarnya peneliti budaya justru dapat membangun teori yang bersifat grass root dan tidak harus mengadopsi teori budaya barat yang belum 
tentu relevan. Penelitian etnosains terhadap fenomena budaya selalu berbasis etno dan atau folk. Kehadiran etnosains, menurut Spradley (2001), memang memberi angin segar pada penelitian budaya. Meskipun hal demikian bukan hal yang baru, karena sebelumnya telah mengenal verstehen (pemahaman), namun tetap memberi wajah baru bagi penelitian budaya. Memang belum ada kesamaan pendapat mengenai istilah etnosains di kalangan peneliti budaya. Istilah ini ada yang menyebut cognitive anthropology, ethnographic semantics, dan descriptive semantics (Spradley, 2001). Berbagai istilah ini muncul karena masing-masing ahli memberikan penekanan berbeda, tetapi hakikatnya adalah ingin mencari tingkat ilmiah kajian budaya. Selanjutnya, perkembangan pendidikan sains sangat dipengaruhi dan didorong oleh pesatnya perkembangan ilmu pengetahuan dan teknologi yang melahirkan sains formal seperti yang diajarkan di berbagai jenjang pendidikan. Sementara itu, di lingkungan masyarakat tradisional terbangun pengetahuan asli berbentuk pengetahuan yang tidak terstruktur secara sistematis dalam bentuk kurikulum yang diimplementasikan dalam pendidikan formal, tetapi berbentuk pesan, amanat yang disampaikan secara turun temurun di suatu masyarakat adat seperti cara memelihara hutan dengan memberlakukan hutan larangan, cara bercocok tanam, dan lain sebagainya. Oleh karena itu, penggalian khusus mengenai pengetahuan asli (indigenous knowledge) di suatu masyarakat menjadi semakin penting untuk dikaji yang pada gilirannya dapat dimanfaatkan oleh bidang sains formal.

Dalam kaitannya dengan etnosains, beberapa karya berikut dijadikan sebagai pijakan pengamatan. Tjitrosoepomo (2013), misalnya, telah membahas sejarah taksonomi tumbuhan yang dapat dibagi ke dalam lima periode, yakni pada abad keempat sebelum masehi, abad keempat sebelum masehi sampai abad ketujuh belas, abad kedelapan belas, abad kedelapan belas sampai pertengahan abad kesembilan belas, dan pertengahan abad kesembilan belas hingga sekarang. Dasar pengklasifikasian tumbuhan menjadi pembeda antara periode satu dan periode lainnya. Selain itu, dibahas pula tata nama tumbuhan yang telah diatur dalam International Code of Botanical Nomenclature atau Kode Internasional Tatanama Tumbuhan.

Suhandano (2000) dalam "Klasifikasi Folk Biologi dalam Bahasa Jawa: Sebuah Pengamatan Awal" mengamati folk biologi di dalam bahasa Jawa. Adapun hasil dari penelitian ini adalah adanya dugaan bahwa di dalam bahasa Jawa, tumbuhan dan hewan memiliki pengklasifikasian yang khas. Selanjutnya, dalam "Leksikon Etnobotani Bahasa Jawa" (2004) Suhandano mengungkapkan cara pandang masyarakat penutur bahasa Jawa terhadap dunia tumbuh-tumbuhan. Selain itu, juga dibahas prinsip-prinsip umum leksikon etnobotani yang berlaku secara lintas bahasa sesuai dengan fakta yang ada dalam bahasa Jawa. Selanjutnya, leksikon etnobotani dalam bahasa Jawa dapat dipilah ke dalam beberapa kelompok menurut kategori etnologi yang dilabelinya, yakni 
leksikon pada kategori generik, leksikon pada kategori bentuk makhluk, leksikon pada kategori spesifik dan varietal, dan leksikon pada kategori antara dan jenis makhluk. Pengidentifikasian tumbuh-tumbuhan didasarkan pada karakteristik fisik dan fungsi tumbuh-tumbuhan dalam kehidupan. Karakteristik tumbuh-tumbuhan ada yang dapat diketahui dari leksikon yang dipakai untuk menandainya karena ada kesesuaian antara makna leksikon dan karakteristik tumbuh-tumbuhan yang diacunya, tetapi ada pula yang tidak.

Selanjutnya, Fernandez (2008) dalam "Kategori dan Ekspresi Linguistik dalam Bahasa Jawa sebagai Cermin Kearifan Lokal Penuturnya: Kajian Etnolinguistik pada Masyarakat Petani dan Nelayan" membahas penguasaan pengetahuan tradisional yang mengutamakan ekologi, hubungan serasi yang terjalin antarmanusia, antara manusia dan sang pencipta, dan antarmanusia. Di dalam uraiannya diketahui adanya sistem pengetahuan masyarakat yang mencerminkan keserasian relasi dalam hubungan di antara manusia dengan ekologi alam sekitarnya, ekologi sosial, dan ekologi pikiran masyarakatnya. Selain itu, ekspresi linguistik tampak pada kosa kata dan paduan kata. Hal ini tercermin dari pola pikir dan pandangan hidup para petani dan nelayan. Sementara, Sarwanto (2010) dalam "Identifikasi Sains Asli (Indigenous Science) Sistem Pranata Mangsa melalui Kajian Etnosains" mengidentifikasi konten sains yang ada pada sistem pranata mangsa dan mengetahui pola pengembangan dan pewarisan pengetahuan sistem pranata mangsa dalam masyarakat Jawa. Hasil dari penelitian ini ialah bahwa sistem kalender itu disusun berdasar titen (observasi) terhadap perubahan letak matahari, rasi bintang, dan keadaan alam yang periodik. Sistem kalender pranata mangsa ini merupakan sistem kalender yang lengkap karena dapat menggabungkan kejadian yang ada di langit (sama') dan bumi (ardli'). Kalender pranata mangsa mengungkap perilaku hewan dan tumbuhan yang ada di Jawa dan karakter tanah yang dipengaruhi oleh perubahan suhu. Dekat dengan itu, Fidiyani dan Kamal (2012) dalam "Penjabaran Hukum Alam Menurut Pikiran Orang Jawa Berdasarkan Pranata Mangsa" menyajikan eksistensi pranata mangsa bagi petani di Kabupaten Banyumas dalam praktiknya dan penjabaran hukum alam menurut pikiran orang Jawa berdasarkan pranata mangsa. Hasil pengamatannya ialah, pertama, masih dijumpainya eksistensi pranata mangsa di Kabupaten Banyumas meskipun kondisinya terancam punah karena tergerus oleh perkembangan ilmu pengetahuan dan teknologi, irigasi yang sudah tertata dengan baik, dan kerumitan perhitungannya. Kedua, pranata mangsa merupakan cara orang Jawa untuk membaca hukum-hukum alam dan tanda-tanda alam yang berujung pada adanya hubungan harmonis antara manusia dan alam.

Terkait dengan proses pengolahan padi, Fitrianingrum (2016) dalam "Bahasa dalam Budaya Jawa terkait Aktivitas Pertanian Padi di Desa Bangsri, Kecamatan Karangpandan, Kabupaten Karanganyar (Kajian Etnolinguistik)" telah mendeskripsikan 
bentuk bahasa dalam budaya Jawa terkait aktivitas pertanian padi di Desa Bangsri, Kecamatan Karangpandan, Kabupaten Karanganyar, mendeskripsikan makna leksikal dan makna kultural yang terangkum dalam bahasa dan budaya Jawa terkait aktivitas pertanian padi di Desa Bangsri, Kecamatan Karangpandan, Kabupaten Karanganyar, dan mendeskripsikan pola pikir, pandangan hidup, dan pandangan terhadap dunia masyarakat petani di Desa Bangsri, Kecamatan Karangpandan, Kabupaten Karanganyar. Dari hasil penelitian aktivitas pertanian padi di Desa Bangsri, Kecamatan Karangpandan, Kabupaten Karanganyar ini ditemukan istilah terkait aktivitas sebelum dan saat menanam padi, sesudah menanam padi, saat panen dan setelah panen padi. Istilah aktivitas tersebut dikelompokkan menjadi bentuk monomorfemis, polimorfemis berupa afiksasi dan kata ulang, bentuk frase, dan bentuk klausa. Penentu makna leksikal istilah aktivitas pertanian padi adalah makna dalam kamus, sedangkan makna kultural istilah aktivitas pertanian padi meliputi tradisi yang mencerminkan cara kerja, tujuan dilakukan aktivitas tersebut. Istilah-istilah aktivitas pertanian padi di Desa Bangsri dapat menjelaskan pola pikir berupa pengetahuan masyarakat setempat yang berisi prinsip-prinsip dan aturan-aturan mempersiapkan benih, mempersiapkan lahan untuk ditanami, merawat tanaman padi, panen, mengelola hasil, dari prinsip-prinsip dan aturan-aturan tersebut dapat diketahui pandangan hidup dan pandangan mereka terhadap dunia. Sementara terkait dengan peralatan pertaniannya, Budhiono (2017) dalam "Leksikon Alat dan Aktivitas Bertanam Padi dalam Bahasa Jawa" secara khusus membahas leksikon alat dan aktivitas bertanam padi dalam subdialek bahasa Jawa yang dituturkan di Pemalang. Ia telah menginventarisasi leksem-leksem alat dan aktivitas bertanam padi, menjabarkan maknanya, dan mencari leksem-leksem yang termasuk dalam satu medan makna yang sama. Leksikon yang termasuk alat bertanam padi meliputi blak, luku, garu, korokan, peret, pacul, dan pancong; sedangkan leksikon yang termasuk dalam aktivitas bertanam padi meliputi nyebar, ngluku, nggaru, tandur, ngorok, derep, matun, gampung, nggejok, lajo, mbaron, pelanggaran, meret, dan nggaleng. Hasil penelitiannya menyatakan bahwa leksem nggaru-ngluku, pacul-pancong, dan nggejogmeret termasuk dalam medan makna yang sama, dan beberapa leksem di antara objek penelitiannya telah menjadi bagian dari kosakata bahasa Indonesia, di antaranya matun, derep, luku, dan garu.

\section{LEKSIKON ETNOSAINS PERTANIAN}

Daerah Istimewa Yogyakarta merupakan daerah istimewa setingkat provinsi yang merupakan peleburan dari Negara Kasultanan Yogyakarta dan Negara Kadipaten Pakualaman. Provinsi ini berbatasan langsung dengan Provinsi Jawa Tengah dan Samudra Hindia. Dengan luas wilayah sebesar 3.185,80 km², wilayah ini terbagi atas 
lima kabupaten, yakni kabupaten Gunung kidul, Kabupaten Sleman, Kabupaten Kulonprogo, Kabupaten Bantul, dan Kotamadya. Daerah Yogyakarta mempunyai potensi lahan pertanian sebesar 23\%, perkebunan 39,73\%, tanaman keras 27\%, dan kawasan lindung 5,2\% dan 5,07\% untuk keperluan lainnya. Adapun pola penggunaan tanah pada saat sekarang ini adalah hutan sebesar 4,78\%, sawah sekitar 21\%, ladang sekitar 34,0\%, pekarangan sekitar 0,035\%, perkebunan 4,35\%, dan sisanya untuk penggunaan lainnya. ${ }^{1}$ Dengan melihat data penggunaan lahan tersebut dapat disimpulkan bahwa sektor pertanian masih mendominasi penggunaan lahan di provinsi ini. Penggunaan lahan pada sektor pertanian ini sebagian besar tersebar di empat kabupaten, yakni di Kabupaten Gunung kidul, Kabupaten Sleman, Kabupaten Kulonprogo, dan Kabupaten Bantul. Kotamadya, sebagai pusat pemerintahan, sebagian besar lahan pertanian sudah beralih fungsi menjadi rumah dan juga tempat usaha. Oleh karena itu, pengambilan data pada penelitian ini hanya dilakukan di empat kabupaten tersebut. Selanjutnya, berdasarkan pengamatan lapangan data yang diperoleh dapat dikelompokkan ke dalam uraian mengenai pengolahan tanah, pemeliharaan tanaman, alat pertanian, jenis tanaman, varietas tanaman, bagian tumbuhan, fase tumbuh tanaman, hama, obat pembasmi hama, sistem pertanian, irigasi, musim, pupuk, penanganan hasil tanam, dan upacara adat seperti tersaji berikut ini.

Dalam proses pengolahan tanah petani di Yogyakarta mengidentifikasi dan menamai aktivitas pengolahan tersebut secara bermacam-macam. Ada yang dinamai berdasarkan alat yang digunakan dalam proses pengolahan tanah (data 1 dan 2), ada yang berdasarkan benda lain yang berkaitan dengan proses pengolahan tanah (data 3-5, dan 7), dan ada yang dinamai karena bunyinya (data 6).

\begin{tabular}{|c|c|c|}
\hline No & Leksikon & Makna \\
\hline 1 & Ditraktor & $\begin{array}{l}\text { Proses penggemburan tanah dengan menggunakan } \\
\text { traktor }\end{array}$ \\
\hline 2 & Dibajak & $\begin{array}{l}\text { Proses mengolah tanah dengan menggunakan alat } \\
\text { bernama traktor, sapi, atau kerbau }\end{array}$ \\
\hline 3 & Diosrok & $\begin{array}{l}\text { Proses pemberantasan gulmadengan menggunakan } \\
\text { garuk }\end{array}$ \\
\hline 4 & Dirabok & Pemupukan tanaman \\
\hline 5 & Digepuki & $\begin{array}{l}\text { proses penghalusan tanah agar tanah dapat bercampur } \\
\text { secara merata dengan pupuk }\end{array}$ \\
\hline 6 & $\begin{array}{l}\text { diunthuk- } \\
\text { unthuk }\end{array}$ & tanah digali menyerupai bentuk gelombang \\
\hline 7 & ditokke & penanaman biji kacang \\
\hline
\end{tabular}

${ }^{1}$ Lihat https://www.tribunnewswiki.com/2020/02/27/daerah-istimewa-yogyakarta-diy). 
Kata ditokke berasal dari bentuk dasar wetu yang kemudian diimbuhi konfiks di-l-ake menjadi diwetokake. Selanjutnya, bentuk diwetokake mengalami proses pengurangan suku kata sehingga menjadi ditokke.

Selanjutnya, leksikon yang terkait dengan pemeliharaan tanaman dapat diidentifikasi berdasarkan kata kerja dalam kegiatan pemeliharaan tanaman dan dapat pula didasarkan pada benda yang digunakan untuk proses pemeliharaan tanaman.

\begin{tabular}{|c|l|l|}
\hline No & \multicolumn{1}{|c|}{ Leksikon } & \multicolumn{1}{c|}{ Makna } \\
\hline 1 & Dikethok & Dipotong \\
\hline 2 & Digrajeni & Digergaji \\
\hline 3 & Dibebah & Ditumbuk \\
\hline 4 & Dipencasi & Dipotong \\
\hline 5 & Didhunke & ditanam di tanah sekaligus diairi \\
\hline 6 & Diwur-wurke & Ditaburkan \\
\hline
\end{tabular}

Pada kelompok alat pertanian ada leksikon yang diidentifikasikan berdasarkan ukurannya seperti pacul (cangkul) dan lengis. Pacul adalah alat yang digunakan untuk menggali atau mengaduk tanah dan lengis adalah suatu alat sejenis pacul yang berukuran lebih kecil. Dari keempat titik pengamatan, ditemukan pula dialek, yaitu pada leksikon osrok dan usruk. Pembeda kedua leksikon tersebut hanyalah fonem $o$ dan $u$. Namun demikian, makna osrok dan usruk sama, yaitu alat pertanian yang biasanya digunakan untuk mencabuti rumput liar yang mengganggu kelangsungan hidup tanaman.

\begin{tabular}{|c|l|l|}
\hline No & \multicolumn{1}{|c|}{ Leksikon } & \multicolumn{1}{c|}{ Makna } \\
\hline 1 & Osrok & Alat pertanian yang digunakan untuk mencabuti rumput liar. \\
\hline 2 & Usruk & Alat pertanian yang digunakan untuk mencabuti rumput liar. \\
\hline 3 & Pacul & Alat yang digunakan untuk menggali atau mengaduk tanah \\
\hline 4 & Lengis & Alat yang mirip dengan cangkul, tetapi bentuknya lebih kecil \\
\hline
\end{tabular}

Leksikon jenis tanaman ada bermacam-macam. Di antaranya adalah asem, pelem, dan kubis. Leksikon jenis tanaman biasanya berupa kata benda atau nomina.

\begin{tabular}{|c|l|l|}
\hline No & Leksikon & \multicolumn{1}{|c|}{ Makna } \\
\hline 1 & Asem & $\begin{array}{l}\text { Jenis pohon yang daunnya digunakan sebagai penanda } \\
\text { musim penghujan }\end{array}$ \\
\hline 2 & Pelem & $\begin{array}{l}\text { Jenis pohon yang menghasilkan buah berwarna kuning } \\
\text { dengan rasa masam yang dalam Bahasa Indonesia disebut } \\
\text { dengan mangga }\end{array}$ \\
\hline 3 & Kubis & $\begin{array}{l}\text { Sejenis sayuran yang berbentuk bulat dan berwarna hijau } \\
\text { muda keputihan }\end{array}$ \\
\hline
\end{tabular}


Bentuk kebahasaan leksikon yang berkaitan dengan jenis tanaman bersifat homogen, sama dengan leksikon yang berkaitan dengan peralatan pertanian. Hal itu disebabkan jenis kata yang termasuk dalam leksikon yang terkait dengan jenis tanaman adalah sama, yaitu kata benda

Dalam pada itu, varietas produk-produk pertanian dapat diidentifikasikan dari banyak sisi. Pertama, varian tersebut dapat diidentifikasikan berdasarkan baunya seperti beras menthik wangi. Kedua, berdasarkan rasanya seperti salak madu. Salak madu dinamai demikian oleh para petani salak karena salak madu memiliki rasa paling manis di antara varian-varian salak yang lain. Ketiga, berdasarkan warnanya seperti salak gading. Salak gading dinamai demikian karena warnanya seperti kuning gading. Keempat, berdasarkan ukuran, baik kuantitas maupun kualitasnya. Salak pondoh super, misalnya, dinamai demikian karena ukuran salak tersebut lebih besar daripada ukuran salak pada umumnya dan rasanya lebih enak daripada salak pondoh biasa. Adapun Mbale Rante adalah salah satu varian bibit salak didasarkan atas daerah asal bibit salak.

\begin{tabular}{|c|l|l|}
\hline No & \multicolumn{1}{|c|}{ Leksikon } & \multicolumn{1}{c|}{ Makna } \\
\hline 1 & $\begin{array}{l}\text { Menthik } \\
\text { wangi }\end{array}$ & Varian padi yang menghasilkan beras berbau wangi \\
\hline 2 & Madu & $\begin{array}{l}\text { Varian salak yang ukurannya kecil, tetapi rasanya paling } \\
\text { manis di antara varian salak yang lain }\end{array}$ \\
\hline 3 & Gading & $\begin{array}{l}\text { Varian salak berwarna kuning yang rasanya tidak manis } \\
\text { dan dapat dimanfaatkan sebagai obat diabetes }\end{array}$ \\
\hline 4 & Pondoh super & Varian salak yang ukurannya besar dan rasanya manis \\
\hline 5 & Mbale rante & Varian bibit salak yang berasal dari daerah Bale Rante \\
\hline
\end{tabular}

Bentuk-bentuk leksikon pertanian yang berkaitan dengan varietas tanaman sangat beragam. Ada yang terdiri atas kata, ada yang terdiri atas gabungan kata, ada yang terdiri atas angka, dan ada yang terdiri atas gabungan huruf dan angka.

\begin{tabular}{|c|l|l|}
\hline No & \multicolumn{1}{|c|}{ Leksikon } & \multicolumn{1}{c|}{ Makna } \\
\hline 1 & Cihera & salah satu varietas tanaman padi \\
\hline 2 & Menthik wangi & salah satu varietas tanaman padi \\
\hline 3 & 64 & salah satu varietas tanaman padi \\
\hline 4 & IR36 & salah satu varietas tanaman padi \\
\hline
\end{tabular}

Penamaan bagian tubuh tumbuhan dalam Bahasa Jawa yang digunakan oleh petani di Yogyakarta ada yang didasarkan pada jantan-betina dan usia. Identifikasi berdasarkan jantan-betina terdapat dalam leksikon kembang wedok dan kembang lanang. Kembang wedok digunakan untuk bunga betina, sedangkan kembang lanang digunakan untuk menyebut bunga jantan tanaman salak. Identifikasi berdasarkan usia tanaman 
misalnya pada tanaman salak yang menamai buah kelapa yang masih kecil dengan sebutan bluluk dan buah kelapa yang sedikit lebih tua dari bluluk, tetapi belum tua, dinamai cengkir.

\begin{tabular}{|c|l|l|}
\hline No & \multicolumn{1}{|c|}{ Leksikon } & \multicolumn{1}{c|}{ Makna } \\
\hline 1 & Kembang wedok & Bunga salak yang mempunyai putik \\
\hline 2 & Kembang lanang & Bunga salak yang mempunyai benang sari \\
\hline 3 & Bluluk & Buah kelapa yang masih kecil \\
\hline 4 & Cengkir & Buah kelapa yang masih muda \\
\hline
\end{tabular}

Terkait fase tumbuh tanaman diperoleh data identifikasi fase tumbuh tanaman yang didasarkan pada kondisi fisik tanaman. Tanaman padi dikatakan dalam masa teklok ketika padi tersebut sudah terlalu tua, sehingga batangnya layu dan rontok. Istilah teklok dalam Bahasa Jawa tidak hanya mengacu pada padi saja, tetapi juga pada orang yang berusia tua dan sakit-sakitan, sehingga tidak bisa banyak bergerak. Adanya persamaan konsep teklok pada manusia dan pada tanaman padi bisa menjadi latar belakang penamaan fase teklok pada padi yang sudah terlalu tua. Istilah kuning dalam fase tumbuh tanaman padi merujuk pada suatu waktu ketika padi sudah dapat dipanen, tetapi masih ada batang yang berwarna hijau. Data lain ihwal fase tumbuh tanaman dapat dilihat berikut ini.

\begin{tabular}{|c|l|l|}
\hline No & \multicolumn{1}{|c|}{ Leksikon } & \multicolumn{1}{c|}{ Makna } \\
\hline 1 & Teklok & $\begin{array}{l}\text { Fase ketika padi sudah terlalu tua sehingga batangnya layu } \\
\text { dan rontok }\end{array}$ \\
\hline 2 & Kuning & $\begin{array}{l}\text { Fase ketika padi sudah waktunya dipanen, tetapi masih } \\
\text { ada yang berwarna hijau }\end{array}$ \\
\hline 3 & Tandur & proses tumbuhnya tanaman padi \\
\hline 4 & Ngretek & proses tumbuhnya tanaman kacang \\
\hline
\end{tabular}

Leksikon tentang hama dapat diidentifikasikan berdasarkan ciri khas dari hewan tersebut. Walang sangit, misalnya, dinamai demikian karena hewan tersebut mengeluarkan bau tidak enak atau bau sangit jika merasa terancam. Data hama lain yang ditemukan ialah wereng.

\begin{tabular}{|c|l|l|}
\hline No & \multicolumn{1}{|c|}{ Leksikon } & \multicolumn{1}{|c|}{ Makna } \\
\hline 1 & Walang sangit & $\begin{array}{l}\text { Serangga yang sering mengganggu tanaman padi dan } \\
\text { baunya tidak enak }\end{array}$ \\
\hline 2 & Wereng & Salah satu jenis hama yang menyerang tanaman padi \\
\hline
\end{tabular}


Saat mengatasi hama petani-petani lokal di Yogyakarta tidak hanya menggunakan obat-obatan kimia, tetapi beberapa di antaranya masih ada yang menggunakan bahan tradisional seperti dong sleresede. Kata dong itu merupakan kependekan dari godong yang berarti 'daun'. Dencil dan gadasil merupakan obat kimia yang biasanya digunakan untuk membasmi hama. Akan tetapi, para petani biasanya tidak mampu mengidentifikasi perbedaan keduanya karena kedua jenis pestisida itu adalah obat dari pemerintah.

\begin{tabular}{|c|l|l|}
\hline No & \multicolumn{1}{|c|}{ Leksikon } & \multicolumn{1}{c|}{ Makna } \\
\hline 1 & Dong Sleresede & $\begin{array}{l}\text { Pembasmi hama tradisional yang terbuat dari daun } \\
\text { dan rasanya pahit }\end{array}$ \\
\hline 2 & Dencil & Sejenis pestisida \\
\hline 3 & Gadacil & Sejenis pestisida \\
\hline
\end{tabular}

Selanjutnya, leksikon-leksikon dalam sistem pertanian dapat disebutkan sebagai berikut.

\begin{tabular}{|c|l|l|}
\hline No & Leksikon & \multicolumn{1}{|c|}{ Makna } \\
\hline 1 & Tumpang sari & $\begin{array}{l}\text { Sistem penanaman yang menanam padi, kacang, dan } \\
\text { jagung dalam satu lahan secara bersamaan }\end{array}$ \\
\hline 2 & Mina padi & $\begin{array}{l}\text { Sistem penanaman yang menanam padi dan memelihara } \\
\text { ikan secara bersamaan dalam satu lahan }\end{array}$ \\
\hline 3 & Campursari & $\begin{array}{l}\text { Sistem penanaman yang menanam kedelai, kacang, dan } \\
\text { jagung dalam satu lahan secara bersamaan }\end{array}$ \\
\hline
\end{tabular}

Sementara dalam sistem irigasi, beberapa istilah berbahasa Jawa seperti tuk dan galengan masih lazim digunakan sampai saat ini. Tuk digunakan untuk menyebut sumber mata air yang digunakan sebagai sumber saluran irigasi. Galengan adalah batas antara satu sawah dengan sawah yang lain yang biasanya terdapat batu di setiap pematangnya.

\begin{tabular}{|c|l|l|}
\hline No & \multicolumn{1}{|c|}{ Leksikon } & \multicolumn{1}{c|}{ Makna } \\
\hline 1 & Tuk & Sumber mata air \\
\hline 2 & Galengan & $\begin{array}{l}\text { Batas antara satu sawah dengan sawah yang lain yang } \\
\text { setiap pematangnya diberi batu }\end{array}$ \\
\hline
\end{tabular}

Dalam hal musim atau mangsa dalam kalender Jawa berperan penting bagi masyarakat petani tradisional. Beberapa di antaranya adalah mangsa rendheng dan mangsa ketiga. Pranata mangsa dihitung seperti dalam kalender bulan atau kalender qomariyah. Berikut tersaji data yang ditemukan. 


\begin{tabular}{|c|l|l|}
\hline No & \multicolumn{1}{|c|}{ Leksikon } & \multicolumn{2}{|c|}{ Makna } \\
\hline 1 & Rendheng & Musim penghujan \\
\hline 2 & Ketiga & Musim kemarau \\
\hline
\end{tabular}

Leksikon pertanian yang berkaitan dengan pupuk, khususnya pupuk alami, dapat diidentifikasikan berdasrkan bahan asal pupuk tersebut. Pupuk kandang dinamai demikian karena terbuat dari kotoran hewan. Kata kandang adalah kata yang dekat dengan dunia hewan. Hal itu sapat melatarbelakangi munculnya istilah pupuk kandang untuk menyebut pupuk tersebut. Pupuk kompos adalah pupuk alami yang terbuat dari dedaunan kering. Pupuk NPK dan Ponska adalah pupuk kimia yang merupakan pupuk modern yang dijual bebas di pasar. Karena harganya yang tidak mahal dan pemakaiannya yang praktis, beberapa petani memilih untuk menggunakan pupuk ini.

\begin{tabular}{|c|l|l|}
\hline No & \multicolumn{1}{|c|}{ Leksikon } & \multicolumn{1}{|c|}{ Makna } \\
\hline 1 & NPK & Sejenis pupuk kimia \\
\hline 2 & Ponska & Sejenis pupuk kimia \\
\hline 3 & Kandang & Pupuk alami yang terbuat dari kotoran hewan \\
\hline 4 & Kompos & Pupuk alami yang terbuat dari dedaunan kering \\
\hline
\end{tabular}

Penanganan hasil tanam dapat diidentifikasi penamaannya berdasarkan alat yang digunakan untuk menangani panen dan dari caranya. Leksikon diret, misalnya, disebut demikian karena dipotong menggunakan arit. Bunyi $i$ dalam arit sering dibunyikan sebagai [I] sehingga muncullah istilah diret. Dipedhal adalah salah satu istilah untuk menyebut proses panen dengan cara mengayuh. Kagiatan mengayuh erat kaitannya dengan sepeda, terutama salah satu bagiannya yang disebut dengan pedhal. Oleh sebab itu, muncul leksikon dipedhal untuk merujuk pada proses memanen padi menggunakan mesin yang dijalankan dengan cara dikayuh.

\begin{tabular}{|c|l|l|}
\hline No & \multicolumn{1}{|c|}{ Leksikon } & \multicolumn{1}{c|}{ Makna } \\
\hline 1 & Diret & Dipotong dengan menggunakan arit. \\
\hline 2 & Dipedhal & $\begin{array}{l}\text { Perontokkan padi dengan menggunakan alat yang } \\
\text { dinamakan } \text { erek }\end{array}$ \\
\hline
\end{tabular}

Selanjutnya, upacara adat yang masih diselenggarakan oleh petani di Yogyakarta adalah rasulan dan ruwahan. Istilah rasulan diperoleh karena hari pelaksanaan upacara tersebut pada bulan Syawal. Karena bulan Syawal memiliki relasi yang dekat dengan hal-hal yang bernuansa islami, maka hal tersebut bisa melatarbelakangi munculnya istilah rasulan dalam tradisi petani Jawa. Ruwahan biasanya dilaksanakan pada akhir atau awal tahun Jawa. 


\begin{tabular}{|c|l|l|}
\hline No & \multicolumn{1}{|c|}{ Leksikon } & \multicolumn{1}{|c|}{ Makna } \\
\hline 1 & Rasulan & $\begin{array}{l}\text { Upacara yang dilaksanakansebagai syukur atas } \\
\text { nikmat panen tahun itu }\end{array}$ \\
\hline 2 & Ruwahan & Upacara untuk menghormati leluhur \\
\hline
\end{tabular}

Pembicaraan ihwal upacara adat berkaitan pula dengan pemilihan hari baik. Pemilihan hari baik berbentuk macam-macam, ada yang berhubungan dengan pemilihan hari untuk menanam, memanen, atau dalam melaksanakan upacara adat. Akan tetapi, tidak semua petani modern memilih hari panen atau hari tanam dengan perhitungan Jawa sebagaimana yang dilakukan oleh pendahulu-pendahulunya. Leksikon lotren dekat dengan kata lotre yang merupakan salah satu istilah dalam perjudian yang mengandalkan keberuntungan. Istilah yang lebih membumi adalah istilah bejan, yaitu mengandalkan keberuntungan. Para petani yang menggunakan sistem lotren atau bejan tidak lagi memperhitungkan secara detail hari dan waktu tanam dan panen karena mereka berpikiran bahwa gagal dan berhasilnya panen itu berdasarkan keberuntungan setiap orang. Sistem o-a dan ngajiret adalah hasil pemikiran dari local genius yang berusaha mempermudah generasi-generasi penerusnya dengan menciptkan istilah $o-a$ dan ngajiret agar mudah dihafal oleh generasi selanjutnya.

\begin{tabular}{|c|l|l|}
\hline No & Leksikon & \multicolumn{1}{|c|}{ Makna } \\
\hline 1 & Lotren & $\begin{array}{l}\text { Mengambil secara acak dan mengandalkan } \\
\text { keberuntungan }\end{array}$ \\
\hline 2 & Bejan & Berdasarkan keberuntungan \\
\hline 3 & Sistem o-a & $\begin{array}{l}\text { Sistem yang digunakan untuk menandai musim } \\
\text { penghujan }\end{array}$ \\
\hline 4 & Ngajiret & $\begin{array}{l}\text { Abreviasi dari mangsa kasanga siji maret yang digunakan } \\
\text { masyarakat untuk menandai bahwa musim hujan akan } \\
\text { segera berakhir }\end{array}$ \\
\hline
\end{tabular}

\section{WAWASAN ETNOSAINS PERTANIAN DALAM MASYARAKAT JAWA}

Pada bagian ini dibahas aspek-aspek kultural yang terdapat di dalam daftar kata yang telah didapat. Pembahasan dilakukan dengan menghubungkan daftar kata yang didapat dan kondisi sosial budaya masyarakat yang menaunginya. Daftar kata pada bagian ini dapat dipandang sebagai refleksi dari cara pikir suatu masyarakat tertentu dengan tujuan mencari kearifan lokal (local wisdom) masyarakat Jawa pada bidang pertanian. 
Penelitian ini mengambil delapan titik pengamatan yang tersebar di empat kabupaten, yakni di Kabupaten Sleman (Kecamatan Seyegan dan Kecamatan Cangkringan), Kabupaten Gunung Kidul (Kecamatan Gedangsari dan Kecamatan Playen), Kabupaten Bantul (Kecamatan Piyungan dan Kecamatan Kretek), dan Kabupaten Kulon Progo (Kecamatan Galur dan Kecamatan Samigaluh). Keempat kabupaten tersebut memiliki keadaan topografi yang berbeda-beda. Keadaan tipografi yang berbeda-beda menyebabkan varian tanaman yang ditanam di tiap-tiap titik pun berbeda-beda. Tidak hanya varian tanaman, tetapi juga terdapat perbedaan dalam hal waktu tanam dan hama yang menyerang tanaman. Berikut dijelaskan beberapa istilah yang berkaitan dengan tanaman yang ditanam oleh masyarakat di delapan lokasi tersebut.

Seperti yang telah dijelaskan sebelumnya, jenis-jenis tanaman yang ditanam dipengaruhi oleh topografi wilayah pengamatan. Oleh karena itu, terdapat perbedaan jenis-jenis tanaman yang ditanam pada daerah satu dan daerah yang lainnya. Daerah Gunung Kidul mengenal varietas padi gogo, yakni salah satu varietas padi yang diwariskan turun-temurun oleh nenek moyang di sana. Varietas ini merupakan varietas terbaik yang ditanam oleh masyarakat di daerah Gunung Kidul. Namun, oleh karena pertumbuhannya yang lambat, hanya segelintir orang saja yang menanam padi jenis ini. Penyebutan istilah gogo didasarkan pada asal dari varietas ini, yakni di daerah lembah Sungai Gangga². Penyebutan kata gangga mengalami penghilangan bunyi nasal di tengah-tengah dan perubahan bunyi a menjadi $o$. Hal ini disebabkan oleh masyarakat Jawa yang susah untuk melafalkan kata gangga sehingga menjadi gogo. Varietas jenis ini hanya dikenal di daerah Gunung Kidul karena varietas ini merupakan varietas yang cocok ditanam di daerah pegunungan yang hangat.

Selain tanaman padi gogo, di daerah Sleman dikenal berbagai macam varietas salak. Salah satu dari varietas salak tersebut adalah varietas salak madu. Varietas salak ini merupakan varietas salak terbaik di Kabupaten Sleman. Varietas ini memiliki rasa yang manis seperti madu. Oleh karena itu, varietas ini disebut dengan salak madu. Varietas salak ini hanya dikenal di Sleman daripada daerah-daerah lainnya karena di daerah pengamatan lain, tidak ada petani yang menanam salak. Selain varietas salak madu, dikenal pula varietas salak gading. Salak jenis ini memiliki rasa yang sedikit lebit lebih sepat daripada varietas jenis lain. Salak jenis ini pun tidak begitu banyak ditanam oleh petani di Sleman karena minat masyarakat terhadap jenis ini tidak terlalu banyak.

2 Periksa http://ubik89.blogspot.co.id/2011/04/bertanam-padi-gogo-dilahan-pmk.html yang diakses pada 28 Oktober 2015 pukul 19.31 WIB, padi gogo berasal dari lembah sungai Gangga, Sungai Brahmaputra, dan lembah Sungai Yangtze. 
Salak ini dikenal dengan salak gading karena kulitnya yang memiliki warna yang lebih cerah daripada kulit salak varietas lain. Adapun warna kulit dari varietas ini disebut oleh masyarakat Jawa sebagai kuning gading. Warna kuning gading merujuk pada warna kuning yang menyerupai gading gajah, yakni putih kekuning-kuningan. Di samping beberapa varietas salak, di masyarakat Jawa juga kenal berbagai macam varietas tanaman pisang. Salah satu varietas yang dikenal di masyarakat Jawa adalah varietas pisang mas. Varietas jenis ini merupakan varietas pisang yang cukup digemari oleh masyarakat karena rasanya yang manis. Oleh karena itu, varietas ini banyak ditanam oleh para petani. Varietas jenis ini disebut dengan mas karena kulit varietas ini memiliki warna kuning cerah mengilap seperti emas.

Selain jenis-jenis tanaman, para petani juga memberi nama pada bagian-bagian tanaman tertentu. Pemberian nama bagian-bagian tanaman ini biasanya dilakukan pada tanaman-tanaman yang telah lama dikenal dan ditanam oleh masyarakat setempat. Pemberian nama pada bagian tanaman ini tidak dilakukan pada tanaman-tanaman baru, misalnya pada pohon kakao.

Salah satu pemberian nama pada bagian-bagian tumbuhan adalah pemberian nama pada bunga tanaman salak. Masyarakat Jawa mengenal bunga salak sebagai ketheker. Pemberian nama ketheker diambil dari kata ngetheker, yakni duduk berdiam diri tidak melakukan apa-apa (Atmodjo, 1990; 143). Dalam satu pohon bunga salak hanya tumbuh satu bunga saja di antara rimbunan batang pohon salak. Oleh karena itu, bunga ini diibaratkan sebagai sebagai seorang manusia atau seekor hewan yang ngetheker, duduk sendiri di antara rimbunnya batang pohon salak.

Tidak berhenti pada penyebutan nama saja, bunga salak pun dibagi menjadi dua, yakni kembang lanang dan kembang wedok. Kembang lanang merujuk pada bunga yang memiliki benang sari, sedangkan kembang wedok merujuk pada bunga yang hanya memiliki putik. Dalam proses perkawinannya para petani biasanya membubuhkan benang sari atau kembang lanang kepada putik atau kembang wedok. Pembubuhan ini dilakukan dengan cara menepuk-nepuk kembang jantan ke arah kembang wedok.

Dari pemberian khusus terhadap bagian-bagian tumbuhan di atas dapat dilihat bahwa para petani memperlakukan tanaman seperti manusia yang hidup. Bunga salak diibaratkan seperti orang yang duduk sendiri dan diberi jenis kelamin seperti halnya manusia atau hewan pada umumnya. Hal ini merupakan sebuah laku atau cara petani untuk menghargai makhluk hidup lainnya dalam hal ini tanaman.

Tidak hanya bagian-bagian tumbuhan, masyarakat Jawa memberi nama pula pada masa pertumbuhan tanaman. Titik pengamatan satu dan titik pengamatan yang lainnya biasanya memiliki penyebutan yang berbeda-beda. Salah satu yang dibahas di sini adalah penyebutan fase pertumbuhan padi di daerah Sleman. Ada beberapa bentuk pertumbuhan tanaman padi yang dikenal oleh masyarakat, yakni tandur, meteng, kemratak, temungkul, kuning, tua, remegag, dan teklok. Pemberian nama pada fase 
pertumbuhan padi ini merupakan salah satu cara para petani untuk menghargai alam yang telah memberi penghidupan kepada mereka. Para petani memandang padi seperti halnya memandang makhluk lainnya yang memiliki fase-fase pertumbuhan dalam kehidupan.

Setiap tanaman tidak bisa terlepas dari gangguan hama dan gulma. Hama adalah hewan yang mengganggu produksi pertanian, sedangkan gulma adalah tanaman pengganggu yang mengganggu pertumbuhan tanaman utama. Hama dan gulma ini pada dasarnya sangat meresahkan petani karena mengganggu produksi pertanian. Akan tetapi, para petani dapat menanggulangi keduanya. Di dunia pertanian petani mengenal berbagai macam jenis hama dan gulma yang mengganggu tanaman. Jenis hama yang pertama adalah walang sangit. Walang sangit biasanya menyerang tanaman padi. Ia mengisap sari-sari padi, sehingga menyebabkan padi menjadi tidak berisi. Kata walang sangit terbentuk dari kata walang, yakni belalang dan kata sangit, yakni bau seperti kerak gosong atau hangus. Pemilihan nama ini didasarkan pada bau tubuh walang sangit yang memiliki bau sangit. Selain walang sangit, hama lain yang menyerang tanaman adalah mentul. Mentul adalah sejenis belatung yang menggerogoti akar tanaman dari dalam tanah. Masyarakat menyebut hama ini mentul karena bentuknya yang gemuk dan cembul. Apabila dipegang, tubuh dari hama ini akan terasa kenyal. Kemudian, seperti yang telah dijelaskan sebelumnya, selain hama tanaman, hal lain yang mengganggu produksi pertanian adalah gulma. Seperti halnya hama, gulma ini pun memiliki berbagai macam jenis. Salah satu jenis gulma yang menyerang tanaman pertanian adalah wedusan. Wedusan adalah salah satu jenis rumput yang memiliki struktur batang yang padat. Kata wedhusan terbentuk dari kata wedhus, yakni bahasa Jawa dari kambing, kemudian diberi imbuhan -an. Gulma ini disebut wedusan karena bau dari gulma ini yang mirip dengan bau kambing. Selain wedusan, gulma lain yang dikenal oleh petani adalah pengukan. Sama halnya dengan wedhusan, gulma ini disebut pengukan karena baunya yang penguk, yakni bau seperti tembakau yang sudah lawas. Selain itu, ada pula gulma lain yang disebut dengan jangkung kuning. Penyebutan ini didasarkan pada bentuk dari batang yang berbentuk memanjang dan berwarna kuning.

Selanjutnya, seperti yang telah dijelaskan di muka perbedaan topografi menyebabkan perbedaan varian tanaman. Oleh karena itu, keadaan alam suatu daerah memengaruhi varian tanaman yang ditanam oleh masyarakat pada daerah tersebut. Selain varian tanaman, perbedaan topografi ini juga mengakibatkan perbedaan cara tanam sehingga masyarakat harus beradaptasi dengan keadaan alam yang melingkupinya. Masyarakat Gunung Kidul mengenal istilah ngare. Istilah ngare adalah istilah yang digunakan untuk menyebut daerah lembah atau daerah dataran rendah, seperti daerah Bantul, daerah Sleman, dan daerah dataran rendah lainnya. Istilah ini hanya dimiliki oleh masyarakat yang tinggal di daerah Gunung Kidul. Selain itu, daerah Gunung Kidul 
juga mengenal istilah gaplek, yakni ketela yang telah dikupas dan dikeringkan. Oleh karena tanah di daerah Gunung Kidul yang tidak subur seperti daerah lainnya, produksi padi di daerah ini pun tidak setinggi daerah lainnya. Dengan melihat keadaan yang demikian, masyarakat pun mencari bahan makanan alternatif sebagai pengganti padi. Ketela menjadi bahan makanan pokok yang dipilih oleh masyarakat Gunung Kidul sebagai bahan makanan alternatif. Ketela yang telah masak dijadikan gaplek dengan cara dikupas dan dikeringkan selama dua sampai tiga hari. Pengolahan ketela menjadi gaplek ini bertujuan agar ketela tersebut bertahan lama.

Masyarakat Gunung Kidul juga mengenal istilah sawah tadah udan, yaitu sawah dengan irigasi yang mengandalkan air hujan. Oleh karena letaknya yang berada di daerah dataran tinggi, pada musim kemarau, sumber air di daerah Gunung Kidul kering, sehingga saat musim kemarau tidak ada air yang dapat dialirkan ke sawah. Hal ini berbeda dengan sawah yang berada di daerah dataran rendah. Di daerah dataran rendah, seperti Bantul, Sleman, Kulon Progo, dan lain sebagainya, saat musim kemarau, persediaan air melimpah, sehingga di daerah tersebut masyarakat masih dapat mengandalkan sistem irigasi yang bersumber dari sungai. Dari sini dapat dilihat bahwa keadaan alam memengaruhi pola pikir suatu masyarakat. Tidak hanya pola pikir, keadaan alam juga memengaruhi gaya hidup suatu masyarakat.

Selanjutnya, untuk mendapatkan produksi pertanian yang maksimal, petani selalu dituntut untuk selalu kreatif. Kreativitas ini dapat dilihat dari teknologi sederhana yang mereka ciptakan, sistem perhitungan tanam, penanggulangan hama, sistem tanam, dan lain sebagainya. Namun, hasil kreativitas petani Jawa ini saat ini mulai ditinggalkan disebabkan perkembangan ilmu pengetahuan dan teknologi yang semakin pesat. Kreativitas yang pertama adalah kreativitas dalam perhitungan masa tanam. Dalam menghitung masa tanam yang tepat, masyarakat Jawa masih menggunakan sistem penanggalan Jawa yang disebut dengan pranata mangsa. Pranata mangsa menggunakan basis peredaran matahari dan gejala alam atau dengan menggunakan ilmu titen. Ilmu titen ini masih dapat dilihat pada masyarakat Gunung Kidul. Masyarakat Gunung Kidul memiliki patokan tersendiri ketika musim kemarau datang, yakni dengan mendengar suara garengpung. Kemudian, untuk mengetahui datangnya musim penghujan, biasanya masyarakat berpatokan pada berseminya berbagai macam umbi-umbian di ladang. Selain itu, daerah Sleman juga mengenal sistem penanaman dengan sistem $\mathrm{O}-\mathrm{A}$ dan $\mathrm{A}-\mathrm{O}$. Sistem $\mathrm{O}-\mathrm{A}$ digunakan untuk menandai musim penghujan, sedangkan sistem A-O digunakan untuk menandai musim kemarau. O merupakan singkatan dari oanas atau 'panas' dan A merupakan singkatan dari adem atau 'dingin'. Sistem ini merupakan sistem penanda musim berdasarkan suhu udara suatu daerah. Apabila dilihat dari penerapan dan kegunaannya, ilmu titen ini dapat digunakan pada bidang apa pun. Meski tidak selalu benar, tetapi ilmu titen ini merupakan salah satu cara manusia untuk membaca dan memahami alam. 
Kreativitas petani juga dapat dilihat dari cara petani dalam menanggulangi hama tanaman. Untuk menanggulangi hama tanaman yang berbentuk serangga, para petani biasanya menyemprotkan suatu ramuan khusus untuk mengusir hama tersebut. Ramuan tersebut terbuat dari daun-daun yang rasanya pahit, seperti daun besi atau daun brotowali, yang ditumbuk dan diperas. Kemudian, perasannya tersebut disemprotkan kepada tanaman supaya bagian tanaman yang diserang oleh hama terasa pahit dan hama itu pun tidak mau memakannya. Selain itu, untuk mengusir hama yang masuk dalam kategori burung, para petani biasanya membuat semacam boneka sederhana yang menyerupai manusia. Boneka ini disebut dengan memedi sawah. Boneka ini kemudian diletakkan di tengah sawah. Adapun tujuan dari pembuatan boneka ini supaya burung mengira bahwa boneka tersebut adalah manusia, sehingga ia tidak berani turun ke sawah. Penyebutan memedi sawah didasarkan pada fungsi dari boneka tersebut, yakni menakut-nakuti burung. Kata memedi berasal dari kata meden-medeni atau 'menakut-nakuti'. Kemudian, kata tersebut mengalami perubahan bunyi, sehingga menjadi memedi. Memedi dapat diartikan sebagai sesuatu yang digunakan untuk menakut-nakuti. Kemudian, oleh karena diletakkan di tengah sawah, maka penyebutannya ditambahkan kata sawah di belakangnya.

Selain penanggulangan hama, kreativitas masyarakat juga dapat dilihat dari sistem penaman yang digunakan. Masyarakat mengenal apa yang disebut sebagai campursari, tumpangsari, dan mina padi. Campursari merupakan suatu sistem tanam yang menanam kedelai, kacang, dan jagung secara bersamaan. Tumpangsari merupakan sistem penanaman yang menanam padi, kacang, dan jagung dalam satu lahan secara bersamaan. Yang terakhir, mina padi adalah sistem penanaman yang menanam padi dan memelihara ikan secara bersamaan dalam satu lahan. Dari ketiga sistem pertanian tersebut, sistem pertanian yang banyak dilakukan adalah tumpangsari dan campursari. Hal ini disebabkan kedua sistem tanam ini sangat baik untuk kesuburan tanaman. Istilah tumpangsari berasal dari kata tumpang dan sari. Tumpang dapat diartikan sebagai 'susunan', sedangkan sari diartikan sebagai 'indah'. Oleh karena itu, tumpangsari dapat diartikan sebagai 'susunan yang indah'. Jadi, dalam satu lahan, padi, kacang, dan jagung ditanam dalam satu lahan secara bersusun dengan rapi. Kemudian, istilah campursari berasal dari kata campur dan sari. Campur diartikan sebagai 'dijadikan satu', sedangkan sari diartikan sebagai 'indah'. Oleh karena itu, campursari dapat diartikan sebagai 'campuran antara kedelai, kacang, dan jagung yang ditanam dalam satu lahan, yang disusun dengan indah'. Meskipun tidak banyak digunakan karena risikonya yang besar, masyarakat masih mengenal apa yang disebut dengan mina padi. Penamaan mina padi berasal dari mina yang berarti 'ikan' dan padi yang berarti 'padi'.

Kemudian, kreativitas para petani juga dapat dilihat dari teknologi yang digunakan untuk penanganan pascapanen. Di beberapa titik pengamatan masyarakat 
mengenal apa yang disebut dengan erek. Erek adalah alat yang digunakan untuk merontokkan padi dengan cara dipedal. Penyebutan istilah erek berasal dari bunyi yang dikeluarkan ketika alat tersebut dipedal, yakni rekerekerekerek. Selain erek, masyarakat juga mengenal alat lain, yakni empyok. Alat ini juga mempunyai fungsi yang sama dengan erek, yakni untuk merontokkan. Akan tetapi, pemakaian alat ini berbeda dengan erek. Perontokan padi dengan menggunakan empyok dilakukan dengan cara memukulmukulkan padi ke empyok. Adapun penyebutan kata empyok berasal dari bunyi yang dikeluarkan oleh empyok ketika padi dipukulkan ke alat tersebut, yakni pyokpyokpyok.

Selanjutnya, masyarakat Jawa masih memiliki kepercayaan tertentu dalam menjalani setiap laku di dalam hidupnya. Hal ini disebabkan oleh kepercayaan animisme dan dinamisme yang masih melekat kuat di dalam masyarakat Jawa. Dalam bidang pertanian, kepercayaan-kepercayaan yang berkaitan dengan laku spiritualitas masih diterapkan di beberapa tempat. Di Gunung Kidul masyarakat masih percaya dengan hari baik untuk memulai menanam, yakni pada hari pasaran legi atau manis. Apabila menanam pada hari tersebut, masyarakat percaya bahwa hasil yang didapat akan manis atau baik. Selain itu, di Gunung Kidul juga masih terdapat kepercayaan untuk tidak menanam pada hari yang bertepatan dengan hari kematian saudaranya. Hari kematian saudaranya itu disebut dengan geblak. Menurut mereka, hari tersebut merupakan hari yang kurang baik untuk memulai menanam karena bertepatan dengan datangnya bencana. Apabila ditelusuri lebih lanjut kepercayaan seperti ini merupakan cara masyarakat untuk menghormati mendiang saudara-saudara mereka. Selain itu, hal ini merupakan salah satu bentuk pengingat untuk mendoakan mendiang saudaranya pada hari tersebut.

Dalam pada itu, dewasa ini teknologi semakin berkembang secara pesat. Berbagai macam penemuan yang bertujuan untuk memudahkan kehidupan manusia semakin banyak ditemukan. Penemuan-penemuan mutakhir ini masuk di berbagai macam sektor kehidupan manusia, tidak terkecuali di dalam sektor pertanian. Di sektor ini, berbagai macam barang dengan teknologi mutakhir terus dikembangkan untuk mendapatkan hasil yang maksimal dalam produksi pertanian. Selain itu, teknologi mutakhir ini juga bertujuan untuk memudahkan manusia untuk mengolah hasil produksi pertanian. Traktor merupakan salah satu contoh kemajuan teknologi yang digunakan oleh para petani. Tidak seperti pembajakan dengan menggunakan kerbau atau sapi, pembajakan dengan menggunakan traktor mempermudah dan mengefisienkan waktu para petani. Hanya dengan mengisi bahan bakar dan mengendarainya, pembajakan sawah pun dapat dilakukan dengan cepat. Selain traktor, teknologi lain yang mendukung produksi pertanian adalah teknologi dalam hal penanganan hama. Dahulu para petani menggunakan cara tradisional untuk memberantas hama, yakni dengan cara menyemprotkan sari dari daun-daun tertentu 
terhadap tanaman. Akan tetapi, sekarang petani banyak memilih untuk menggunakan pestisida, yakni semacam senyawa kimia yang berfungsi untuk membunuh hama. Para petani memilih untuk menggunakan pestisida karena dinilai lebih praktis dari pada menggunakan cara-cara tradisional. Tidak hanya dalam hal penanganan hama, sistem pengairan pun mengalami perubahan oleh karena perkembangan teknologi.

Dahulu, para petani hanya mengandalkan datangnya hujan dalam bertani. Meskipun di daerah Gunung Kidul masih menggunakan sistem ini, tetapi berdasarkan pengamatan penulis di lapangan, para petani di daerah lain sudah tidak menggunakan sistem ini. Sebagai contoh, di daerah Galur, Kulon Progo, petani setempat tidak lagi hanya mengandalkan air hujan, tetapi juga sudah menggunakan air dari bendungan. Sungai Progo dibendung dan airnya dialirkan ke sawah-sawah para petani melalui parit yang dibuat oleh pemerintah. Hal yang sama juga terlihat di daerah Kretek, Bantul. Di daerah ini dibuat parit-parit yang digunakan untuk mengalirkan air dari Sungai Opak ke sawah-sawah petani. Oleh karena kemajuan teknologi ini, para petani tidak lagi bergantung pada air hujan sebagai sumber air. Selain dalam bidang irigasi, kemajuan teknologi juga terlihat pada varietas padi yang ditanam oleh petani. Sebelumnya, petani hanya mengenal padi lokal. Akan tetapi, karena perkembangan teknologi, terus dikembangkan berbagai macam varietas padi, seperti padi 64, Cihera, Cinta Mas, IR36 dan lain sebagainya. Varietas-varietas ini merupakan varietas yang diperkenalkan oleh pemerintah. Pada masa orde baru, pemerintahan Soeharto mewajibkan para petani untuk menanam padi varietas IR36 untuk meningkatkan swasembada pangan.

\section{PENUTUP}

Paparan di atas memperlihatkan bagaimana masyarakat pertanian di Yogyakarta secara kebahasaan berada di persimpangan jalan, antara menggunakan sejumlah leksikon baru yang bertambah seiring dengan perkembangan zaman dan melestarikan peristilahan pertanian yang telah tertanam sebagai bagian dari kearifan lokal. Penggunaan unsur-unsur kebahasaan dalam bidang pertanian itu meliputi kata, abreviasi, dan gabungan kata. Istilah pertanian yang berupa kata terdiri, baik dari kata monomorfemik maupun kata polimorfemik. Istilah linguistik yang menggunakan abreviasi meliputi akronim dan singkatan. Dari pengamatan atas data yang terkumpul tampak bahwa sejumlah kata atau istilah baru diterima apa adanya karena tidak ada pelambang yg tepat dalam khazanah leksikon lama, diterima dengan adaptasi seperlunya, dan sejumlah leksikon lama tetap digunakan karena dianggap sudah mencukupi. Leksikon baru yang diterima apa adanya seperti penamaan varietas padi dan pupuknya. Leksikon yang diadaptasi meliputi peristilahan dalam proses pengolahan tanah yang didasarkan atas alat, proses pengolahan tanah, bahkan bunyinya. Terkait 
dengan varietas produk-produk pertanian, penamaannya didasarkan atas bau, rasa, warna, dan ukuran. Adapun leksikon lama yg tetap dipertahankan dan telah terintegrasi dalam praktik-praktik di sektor pertanian adalah hama dan obat tradisionalnya, sistem pertanian, sistem irigasi, dan sistem waktu bertani (pranata mangsa). Pemertahanan leksikon ini dilakukan karena mengandung nilai-nilai kearifan lokal, seperti menjaga keseimbangan alam, menjaga relasi antarpersonal dalam budaya pertanian, dan menjaga relasi antara mereka dan leluhurnya. Demikianlah, budaya pertanian turut membentuk penggunaan aspek kebahasaan yang kompromis antara perkembangan zaman dan nilai-nilai kearifan lokal yang telah jauh tertanam dalam masyarakat pertanian di Yogyakarta.

\section{DAFTAR PUSTAKA}

Atmodjo, S. Prawiro. (1990). Bausastra Jawa. Cetakan kedua. Surabaya: Yayasan Djojo bojo.

Budhiono, R. Hery \& Balai Bahasa Kalimantan Tengah. (2017). Leksikon Alat dan Aktivitas Bertanam Padi dalam Bahasa Jawa. Jurnal Kandai 13, no. 2. 235-248.

Fernandez, Inyo Yos. (2008). Kategori dan Ekspresi Linguistik dalam Bahasa Jawa sebagai Cermin Kearifan Lokal Penuturnya: Kajian Etnolinguistik pada Masyarakat Petani dan Nelayan. Kajian Linguistik dan Sastra, Vol. 20, No. 2, Desember 2008. 166-177.

Fidiyani, Rini \& Ubaidillah K. (2012). Hukum Alam Menurut Pikiran Orang Jawa Berdasarkan Pranata Mangsa. Jurnal Dinamika Hukum Vol. 12, No. 3, September 2012. $421-436$.

Fitrianingrum, Wahyu. (2016). Bahasa dalam budaya jawa terkait aktivitas pertanian padi di Desa Bangsri Kecamatan Karangpandan Kabupaten Karanganyar: Kajian Etnolinguistik). Skripsi. Surakarta: Program Studi Sastra Daerah Fakultas Ilmu Budaya Universitas Sebelas Maret.

Moore, Henrietta L., (1998). Feminisme dan Antropologi (Penerjemah: Tim Proyek Studi Jender dan Pembangunan FISIP UI). Jakarta: Obor.

Sarwanto, (2010). Identifikasi Sains Asli (Indigenous Science) Sistem Pranata Mangsa melalui Kajian Etnosains. Makalah Seminar Pendidikan Biologi Fakultas Keguruan dan Ilmu Pendidikan Universitas Sebelas Maret Surakarta.

Spradley, L.P. (2001). The Ethnographic Interview. New York: Holt, Rinehart, and Wiston. 
Suhandano. (2000). Klasifikasi Folk Biologi dalam Bahasa Jawa: Sebuah Pengamatan Awal. Jurnal Humaniora. Volume XII. No 2/ 2000. 225-230 .

Suhandano, (et.al.). (2004). Leksikon Etnobotani Bahasa Jawa. Jurnal Humaniora Volume 16 No. 3, Oktober 2004. 229-241.

Tjitrosoepomo, Gembong. (2013). Taksonomi Umum: Dasar-Dasar Taksonomi Tumbuhan. Cetakan kelima. Yogyakarta: Gadjah Mada University Press.

\section{DAFTAR LAMAN}

http://ubik89.blogspot.co.id/2011/04/bertanam-padi-gogo-dilahan-pmk.html. 28 Oktober 2015. 19.31.

https://www.tribunnewswiki.com/2020/02/27/daerah-istimewa-yogyakarta-diy. 29 Oktober 2015. 10.16 